\title{
NON-BUSINESSMEN AS SURROGATES FOR BUSINESSMEN IN BEHAVIORAL EXPERIMENTS*
}

\section{BERNARD ALPERT $†$}

W ITH the inclusion of behavioral courses in the business colleges, the results of behavioral experiments are being used as a basis for proposing resolutions to simulated business problems. But often it is not known if the results of such experiments are valid for drawing conclusions about behavior of businessmen. In many behavioral experiments, the samples have been drawn from the student population, ranging from nursery school to college, or else they have been drawn from military organizations, the next most accessible source of subjects. ${ }^{1}$ Usually the subjects were not businessmen. Thus, in relating the conclusions about behavior of nonbusinessmen to behavior of businessmen in the business situation, a distinct danger of bias exists in the sample. This paper focuses on the validity and reliability of the sample when using the results of behavioral experiments to simulate behavior of the businessman in the business situation.

To test the validity of using the response of non-businessmen to resolve business problems, a controlled experiment was conducted, in which military personnel and college students were

*This paper is drawn from the author's unpublished doctoral dissertation, "The Impact of Written Advocacy on One's Own Opinion concerning a Conflict Situation: An Experiment with Business, Military, and Student Groups" (College of Business Administration, University of Washington, 1964). The author wishes to acknowledge the critical evaluation and helpful ideas for interpreting the findings that were offered by Professors Jim Rosenzweig and Leonard Goldberg.

$\uparrow$ Associate professor of management, San Francisco State College.

I Subjects are those persons being tested. tested simultaneously with businessmen in comparing opinions on a manager's method of firing his subordinate. The individual subjects were asked to generate arguments to themselves either approving or disapproving of the manager's method. The opinion changes resulting from the arguments were compared statistically to determine their level of significance. A hypothesis was formulated for testing: that each of five separate categories of subjects would change opinion significantly and in a comparable manner after advocating either in favor of, or against, the manager's method of firing his subordinate. In the actual experiment, null hypotheses were tested.

\section{METHOD}

SAMTPLE

The sample of 301 subjects who participated in this experiment was drawn from residents in or near the city of Seattle, Washington. Subjects were contacted in nineteen separate groups of five to thirty-five persons each. The categories of subjects consisted of 74 business managers; 67 business non-managers; 45 military personnel; 77 upper-division students who were taking or had taken a course entitled "Human Relations in Business," given at the University of Washington, College of Business Administration; and 38 lower-division student engineers who had not taken the "Human Relations in Business" course. ${ }^{2}$

IIn order to distinguish the two categories of students in the body of this paper, those who had taken or were taking the course entitled "Human Relations in Business" were referred to as "upper-division students"; the lower-division student engineers, who had not yet taken the "Human Relations in 
Initially, 405 persons agreed to par-: ticipate as subjects in the experiment, but approximately one-fourth were rejected because they did not meet the rules or requirements of the experiment (such as preparing a letter from a specific point of view by a certain date). A committee of three judged the decisions to accept or reject the participants, with full agreement on more than 99 per cent of the decisions. The rules for acceptance of subjects were sufficiently precise to make full agreement by the judges likely.

\section{CONYLICT SITUATION}

The conflict business situation that was presented to the subjects for judging was drawn from a case study in which a manager abruptly discharged his subordinate after several months of seemingly satisfactory performance. ${ }^{\mathrm{a}}$

\section{PROCEDURE}

The researcher met with each group of subjects twice. At the first meeting, the two questionnaires and the letter of advocacy were described briefly. Then, the subjects were given printed copies of the case and questionnaires to complete. After reading the case, each subject filled in the questionnaire with his opinion of the manager's method of firing his subordinate. Following this, the subjects were asked to prepare individual letters, called "letter of advocacy," for submission one week later at the second meeting. Also, they were asked not to discuss the incident with others. At the second meeting, after the letters of advocacy had been collected, the subjects were

Business" course, were referred to as "student engineers."

The Raymond Optical Company, in Robert Dubin, Human Relations in Adminislration, wilh Readings and Cases (2d ed. [C]; Englewood Cliffs, N.J.: Prentice-Hall, Inc., 1961 [with permission of the publisher]). given a second questionnaire on which to record their second opinions of the manager's method of firing the subordinate. The second questionnaires were duplicates of the first questionnaires.

\section{LETTER OP ADVOCACY AND POINT OF VIEW ADVOCATED}

The letter of advocacy was the subject's effort, in writing, to support the point of view assigned him. One point of view had the subject approving the manager's method of firing the subordinate; the other point of view had him disapproving. As a control device, a small group of thirty-two subjects was not asked to prepare a letter of advocacy.

Assignment of the point of view to be advocated was made immediately after the completed questionnaires had been collected and sorted. First the questionnaires were sorted into two stacks and then each stack into two smaller stacks. The first sorting was based on first opinion, with one stack representing subjects who approved of the manager's method of firing the subordinate and the other representing those who disapproved. Subjects with neutral opinions were divided between the two. The second sorting was mechanical, with questionnaires being placed more or less alternately into one and then into the other smaller stack. Thus, the individual smaller stacks, or cells, were uneven in size.

Subjects from one group of each of the smaller stacks were assigned to advocate in favor of the manager's method, and those in the other smaller stacks were assigned to advocate against the manager's method. Thus, within each of the two fractions of the sample, some of each category advocated the point of view that was congruent with their own opinion, and the others advocated the point of view that was contrary with their own. The questionnaires had been precoded, 
thus.permitting the researcher to assign to each subject an individual number that subsequently was used for collating the before-and-after data and the letter of advocacy. To minimize confusion, the two points of view to be advocated were distributed to the subjects as preprinted topics on colored sheets of paper. The topics were either "Justifying My Method of Firing Mr. Dixon," or else "Why the Manager's Method of Firing Me Was Wrong, and What $\mathrm{He}$ Should Have Done."

The letter of advocacy served to assure the researcher that each subject did indeed advocate the point of view assigned to him. Furthermore, the multiple strati- segments or class intervals, representing five opinions, which from left to right were designated: manager strongly right, manager mildly right, no opinion or weak opinion, manager mildly wrong, and manager strongly wrong.

The recording device was a modification of a scale that Rensis Likert had used to measure an individual's attitude on a controversial incident or topic. ${ }^{4}$ Likert divided his scale into five equally spaced sections for recording each subject's attitude. To each gradation, he applied a numerical value, using the integers $1,2,3,4$, and 5 , with 1 and 5 being the extremes. In this experiment on advocacy, the scale was graded from 0 to

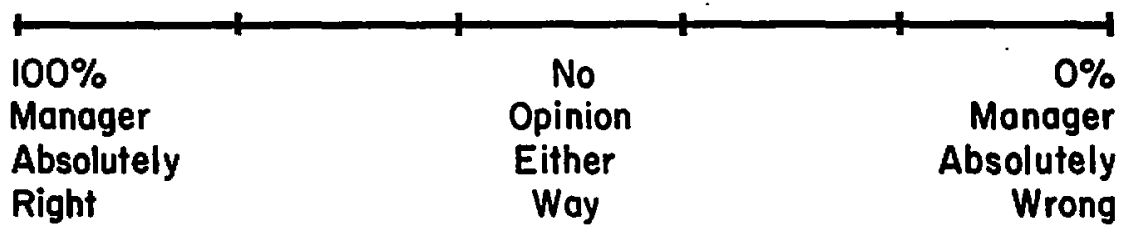

Fro. 1.-Device for the subjects of the experiment to record their opinions

fications of the sample, and chance assignment of point of view to be advocated, provided assurance against bias in the sample categories and in the topic. Consequently, if change in opinion for both groups of advocates had occurred toward one point of view and not toward the other, then the change could have been reasonably attributed to bias in the topic, or else to bias in the sample. But, if change in opinion occurred in each case toward the point of view advocated, then the danger of bias in the topic or in the sample would have been minimized.

OPINION MEASUREMTENT

The subject recorded his opinion on a questionnaire which contained a 5-inch straight line that represented an approval-disapproval continuum (see Fig. 1). The line was divided into five equal
100 in percentages, with 0-19 and 80-100 representing the extremes. After each subject recorded both opinions on the scale, the opinions were quantified. For example, an opinion that the manager was absolutely wrong would record at 0 per cent, and an opinion that the manager was mildly wrong would record somewhere between 20 and 39 per cent. Then, the lateral difference between first and second opinions was calculated for each subject, with the difference indicating the relative amount of opinion change.

\section{STATISTICS}

Both the $t$-and $F$-tests were used. The $F$-ratio for analysis of variance, with one criterion of classification, was used to de-

- Rensis Likert, "A Technique for the Measurement of Attitudes," Arclives of Psychology, CXI. (1932), 1-55. 
termine the significance of difference-ofopinion means among the five groups. ${ }^{b}$ The tratio for dependent samples (or matched pairs) was used to determine the significance of mean difference in opinion (between first and second opinions) of each of the groups. ${ }^{\circ}$

\section{RESULTS}

The subsample size and mean, standard deviations, and standard errors of the means of first opinions of the subjects are presented by occupational category in the manager's action as being mildly wrong. The fifth category, student engineers, evidenced a mean weak opinion of the action. An $F$-ratio at the .05 level of significance indicated that a significant difference existed between the student engineers' opinions compared with the mean opinions of the other four categories.

\section{OPNNION CRANGE AND COMPARISONS}

Table 2 presents in comparative form opinion change for each category of sub-

TABLE 1

FIRST OPINION OF 301 SUBJECTS ON MANAgER's METHOD OF FIRING THE SUBORdINATE CaTEGORIEED BY OCCUPATION

\begin{tabular}{|c|c|c|c|c|}
\hline Subject Category & $\boldsymbol{N}$ & $\underset{\text { Oploan }}{\text { Mean }}$ & S.D. & $s_{\bar{\Sigma}}$ \\
\hline 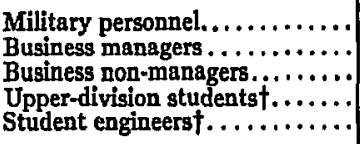 & $\begin{array}{l}45 \\
74 \\
67 \\
77 \\
38\end{array}$ & $\begin{array}{l}29.7 \\
24.2 \\
26.5 \\
20.8 \\
44.2\end{array}$ & $\begin{array}{l}32.2 \\
29.0 \\
29.4 \\
24.8 \\
30.2\end{array}$ & $\begin{array}{l}4.80 \\
3.37 \\
3.59 \\
2.82 \\
4.89\end{array}$ \\
\hline All subjects................. & 301 & 27.2 & 29.4 & 1.69 \\
\hline
\end{tabular}

- Perceatages (see Btg. 1).

$t$ Upper-division studenta were taking a course in human relations. The student engineers were scheduled to take the human relations course but had not yet taken it.

Table 1. Table 2 shows the effects on the subjects' opinions, also by category, after they had advocated to themselves one of the two opposing points of view on the manager's method of firing the subordinate. As hypothesized, advocacy tended to have an effect on the sampled opinians, but the effect was not uniform. ${ }^{7}$

\section{COMPARISON OF FIRST OPINIONS}

As Table 1 shows, the initial mean response of the subject categories to the manager's method of firing the subordinate indicated that four categories viewed

- See F. E. Croxton and D. J. Cowden, Applied General Slatistics (2d ed. rev.; Englewood Cliffs, N.J.: Prentice Hall, Inc., 1955), pp. 706-9.

- See Edward C. Bryant, Statistical Analysis (New York: McGraw-Hill Book Co., 1960), p. 93. jects, standard errors of the means, and results of the $t$-test for matched pairs, for the subsamples of each category that advocated opposite points of view. As a category, military personnel showed the least significant opinion changes in advocating either of the two points of view. On the other extreme, business managers showed rather highly significant changes irrespective of point of view advocated. The business non-managers showed changes that were much more significant when advocating that the manager was right than when they advocated that he was wrong.

7 The control group evidenced much less significant opinion change (see Table 2). 
Apparently the ceilings on possible change had an effect on the actual change evidenced by some of the categories. The greatest amount of change took place where opportunity to change was greatest. Thus, the student engineers, who were initially most inclined to agree with the manager, showed the largest and most significant changes of all those assigned to argue that the manager was wrong. flects experience that tempers his reaction sufficiently to differentiate it qualitatively from that of military personnel. Students, also, may be reflecting an entirely different point of view that colors their responses. In any case, it was concluded that the best subjects for tests designed to reflect the businessman's behavior in the business setting for use in the schools of business is the businessman himself.

TABLE 2

Opinion Change of Subjects advocating Approval or Disapproval, of the Manager's METHOD OF FIRING HIS SUBORdINATE CATEGORIZED BY OCCUPATION

\begin{tabular}{|c|c|c|c|c|c|c|c|c|c|c|}
\hline \multirow{3}{*}{ Sugject ChtzoOzY } & \multicolumn{10}{|c|}{ Ponnt or View AdVocated } \\
\hline & \multicolumn{5}{|c|}{ Manager's Method Was Right } & \multicolumn{5}{|c|}{ Manager's Method Was Wrong } \\
\hline & $N$ & D & $S_{x}^{*}$ & $t$ & $\boldsymbol{P}_{t} \boldsymbol{\dagger}$ & $N$ & $D$ & $5 x^{*}$ & $\bullet$ & $P_{t} \boldsymbol{t}$ \\
\hline $\begin{array}{l}\text { Military personnel.......... } \\
\text { Business managers......... } \\
\text { Business non-managers..... } \\
\text { Upper-division students... } \\
\text { Student engineers. ....... }\end{array}$ & $\begin{array}{l}31 \\
43 \\
38 \\
24 \\
18\end{array}$ & $\begin{array}{r}8.9 \\
17.6 \\
18.5 \\
14.5 \\
11.8\end{array}$ & $\begin{array}{l}4.97 \\
3.10 \\
4.24 \\
3.43 \\
6.89\end{array}$ & $\begin{array}{l}1.79 \\
5.71 \\
4.37 \\
4.23 \\
1.71\end{array}$ & $\begin{array}{l}.04 \\
\ddagger \\
\ddagger \\
.05\end{array}$ & $\begin{array}{l}14 \\
31 \\
28 \\
22 \\
20\end{array}$ & $\begin{array}{r}12.1 \\
8.6 \\
3.5 \\
5.1 \\
16.9\end{array}$ & $\begin{array}{l}10.8 \\
3.85 \\
5.11 \\
2.94 \\
5.59\end{array}$ & $\begin{array}{l}1.12 \\
2.23 \\
0.68 \\
1.73 \\
3.03\end{array}$ & $\begin{array}{l}.16 \\
.02 \\
.24 \\
.05 \\
\ddagger\end{array}$ \\
\hline All advocates. . & 154 & 14.9 & 1.93 & 7.73 & $\ddagger$ & 115 & 8.5 & 2.36 & 3.62 & $\ddagger$ \\
\hline Non-advocates......... & 32 & 2.6 & 2.80 & 0.93 & .348 & & & & & \\
\hline
\end{tabular}

* On this table, $S_{x}$ is the standard etror of $D$.

T The columns headed $P_{1}$ give the approximate probabilities of seeuring such a large value for $t$ if the true average opinion change (D) were zero. Probablities for advocales are based on a one-tailed test, since the average change was always erpected to be (and Was) in the advocated direction.

\$Denotes probabilities of less than .01.

5 Two-talled test.

\section{CONCLUSTONS}

The results of the experiment cast doubt on the validity of the practice of interpreting business behavior based on the results of behavioral experiments in which non-businessmen or else unknown subjects surrogated for businessmen. If, as demonstrated in this experiment, there can be a variety of reactions to a business situation, then use of the nonbusinessman surrogate is not reliable.

It may be that the businessman re-
Furthermore, the results of this experiment indicated support for the idea that some jobs can be handled more appropriately by persons with certain backgrounds. The possible different responses to stimuli may be of value in placement of persons in negotiating or managerial jobs, using those more likely to change when change is desirable, and using those less likely to change when the opposite consequence is sought. 